\title{
Useful plants in the Park Bandro and its surroundings, Lake Alaotra, Madagascar
}

\author{
Nivo H. Rakotoarivelo', Nadiah V. Manjato', Lala R. \\ Andriamiarisoal, Roger Bernard', Sylvie \\ Andriambololoneral
}

\author{
Correspondence: \\ Nivo H. Rakotoarivelo \\ Missouri Botanical Garden \\ Madagascar Research and Conservation Program \\ BP 3391, Antananarivo 101, Madagascar \\ Email: nivo.rakotoarivelo@mobot-mg.org
}

\begin{abstract}
Traditional use of plants constitutes an important activity in Malagasy life, especially in the countryside. The Sihanaka group is found in the east of Lake Alaotra and is the dominant cultural group in the lake region, including in the Fokontany of Andreba Gara, near Park Bandro, in the east of Lake Alaotra, in Ambatondrazaka district where the study was conducted. The Sihanaka holds traditional knowledge on plant uses and makes use of this knowledge in their daily lives. The objective of this study was to describe the use of aquatic plants in the region to better understand the importance of the Alaotra wetlands in the lives of local people. Surveys conducted among the people of Andreba, including one traditional chief (the Tangalamena) and one healer, revealed 55 useful species of aquatic plants, grouped into 41 genera and 23 families. Most species were used for their medicinal and veterinary virtues (32 species), for animal food (17 species), as utensils and tools (16 species), for cultural uses (10 species), and for human food (9 species). Leaves (76\%) are the most exploited plant parts. The species with the most uses were Cyperus papyrus subsp. madagascariensis (Willd.) Kük. with 26 types of use recorded, then Phragmites australis (Cav.) Trin. ex Steud. (19 types of use), Aeschynomene elaphroxylon (Guill. \& Perr.) Taub. and Eichhornia crassipes (Mart.) Solms (12 types of use each). Nymphaea nouchali, cyperus papyrus subsp. madagascariensis and Phragmites australis were the species most frequently cited by informants, indicating that they are important for the local population. The most frequently cited types of use included joro, namely ancestor's invocation, food, materials for house walls construction, herbal teas to treat ailments, and fencing or demarcation of land boundaries. This study highlighted the importance of the Alaotra wetlands as a source of useful plants for the local population. Sustainable management of Lake Alaotra is therefore not just necessary for biodiversity conservation, but also for maintaining local livelihoods.
\end{abstract}

\section{RÉSUMÉ}

L'utilisation traditionnelle des plantes constitue une activité importante dans la vie des Malgaches, plus particulièrement dans les campagnes. Le groupe Sihanaka est rencontré à l'est du lac
Alaotra et constitue le groupe culturel dominant dans la région du lac, y compris dans le Fokontany d'Andreba Gara, près du Parc Bandro, à I'Est du Lac Alaotra, dans le district d'Ambatondrazaka où l'étude a été menée. Les Sihanaka détiennent des connaissances traditionnelles sur l'utilisation des plantes et utilisent ces connaissances dans leur vie quotidienne. L'objectif de cette étude était de décrire I'utilisation des plantes aquatiques dans la région afin de mieux comprendre l'importance des zones humides de l'Alaotra dans la vie des populations locales. Des enquêtes menées auprès de la population d'Andreba, y compris auprès d'un chef traditionnel (le Tangalamena) et d'un guérisseur, ont révélé 55 espèces utiles de plantes aquatiques, regroupées dans 41 genres et 23 familles. La plupart des espèces étaient utilisées pour leurs vertus médicinales et vétérinaires (32 espèces), pour l'alimentation des animaux (17 espèces), en tant qu'ustensiles et outils (16 espèces), pour des usages culturels (10 espèces) et pour l'alimentation humaine (9 espèces). Les feuilles (76\%) sont les parties de plante les plus exploitées. Les espèces ayant le plus d'utilisations étaient Cyperus papyrus subsp. madagascariensis (Willd.) Kük. avec 26 types d'utilisation recensés, puis Phragmites australis (Cav.) Trin. ex Steud. (19 types d'utilisation), Aeschynomene elaphroxylon (Guill. \& Perr.) Taub. et Eichhornia crassipes (Mart.) Solms (12 types d'utilisation chacune). Nymphaea nouchali, Cyperus papyrus subsp. madagascariensis et Phragmites australis étaient les espèces les plus fréquemment citées par les informateurs, ce qui indique qu'elles sont importantes pour la population locale. Les types d'utilisation les plus fréquemment cités comprenaient le joro à savoir l'invocation des ancêtres, I'alimentation, les matériaux pour la construction des murs, les tisanes pour traiter les maladies et la construction de clôtures ou démarcation des limites de terrains. Cette étude a souligné l'importance des zones humides de l'Alaotra en tant que source de plantes utiles pour la population locale. La gestion durable du lac Alaotra n'est donc pas seulement nécessaire à la conservation de la biodiversité mais également au maintien des moyens de subsistance locaux. 


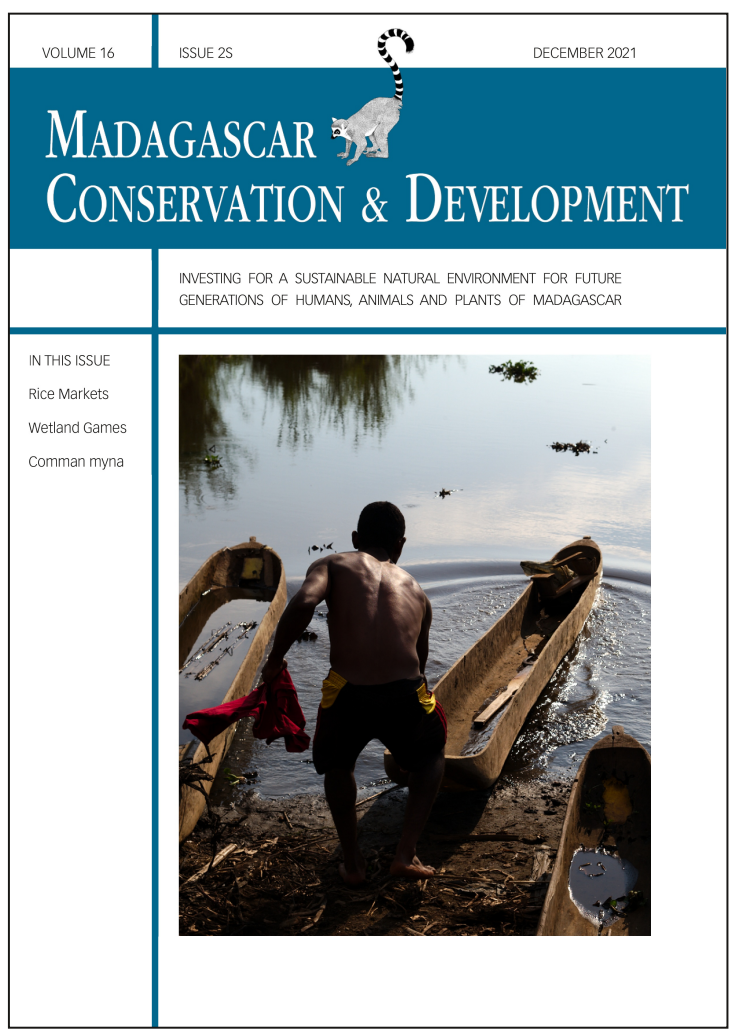

Madagascar Conservation \& Development is the journal of Indian Ocean e-Ink. It is produced under the responsibility of this institution. The views expressed in contributions to MCD are solely those of the authors and not those of the journal editors or the publisher.

All the Issues and articles are freely available at https://www.journalmcd.com

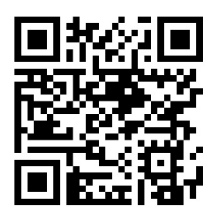

Contact Journal MCD

info@journalmcd.net for general inquiries regarding MCD funding@journalmcd.net to support the journal

Madagascar Conservation \& Development Institute and Museum of Anthropology

University of Zurich

Winterthurerstrasse 190

CH-8057 Zurich

Switzerland

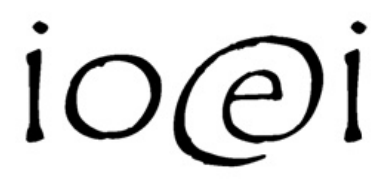

Indian Ocean e-Ink

Promoting African Publishing and Education

www.ioeink.com

Missouri Botanical Garden (MBG)

Madagascar Research and Conservation Program

Missouri Botanical Garden

BP 3391

Antananarivo, 101, Madagascar 


\section{INTRODUCTION}

Madagascar's freshwater wetlands include more than $3000 \mathrm{~km}$ of rivers and streams, and about $2000 \mathrm{~km}^{2}$ of lakes (Chaperon et al. 1993). Currently, 20 wetlands of international importance are designated as Ramsar sites, including Lake Alaotra which is the largest freshwater lake in Madagascar. Established in 2003, and with a surface area of about 722,500 ha, the Alaotra wetlands are Madagascar's third Ramsar site after the Complexe des lacs de Manambolomaty and Tsimanampetsotse National Park that were both established in 1998 (Ramsar 2018). Lake Alaotra was officially recognized as a temporary New Protected Area in 2007. In June 2015, the area was designated a new protected area (IUCN Category V) (Waeber et al. 2017) by the Government of Madagascar.

Wetlands are critical for the livelihoods of those living in their vicinity, supporting provisioning services such as domestic water supply, fisheries, livestock grazing, cultivation, construction materials, and wild plants for food and medicinal use (Schuyt and Brander 2004, McCartney et al. 2010, Darwall et al. 2011). Moreover, wetlands support a highly diverse flora and fauna (Darwall et al. 2011). Lake Alaotra has a particularly high socio-economic importance because the surrounding landscape constitutes the largest rice granary in Madagascar, and the lake is well known for fish production (Pidgeon 1996, Andrianandrasana et al. 2005, Ranarijaona 2007, Copsey et al. 2009). In addition, the marshes are traditionally used by the resident population as a source of raw materials for construction, handicrafts, furniture manufacturing, and as hunting and fishing areas (Ramsar 2003, Rendigs et al. 2015). Unfortunately, the burning of marshes, the conversion of marshes to rice fields, and siltation reduced the area of both the marshes and the lake. The lake is very vulnerable to siltation because it is shallow with a maximum depth of just $4 \mathrm{~m}$ during the rainy season (Pidgeon 1996). Marshland and its biodiversity is disappearing "in a puff of smoke" with an average of 3000 ha burnt annually between the years 2000 and 2009 (Ratsimbazafy et al. 2013, Rendigs et al. 2015). An extreme year for fires was observed in 2012 with over 159 single fires recorded during the peak drought period, within less than three months (Ratsimbazafy et al. 2013). Further problems include the invasion of non-native plant species, such as the water hyacinth, Eichhornia crassipes, and the water ferns Salvinia molesta and Azolla spp. (Andrianandrasana et al. 2005, Lammers et al. 2015). While changes in plant community composition and structure have been noticed, the knowledge about the lake's flora is incomplete and outdated (Lammers et al. 2015), and biodiversity loss could lead to traditional knowledge loss on plant uses. Documentation on traditional knowledge of aquatic plant uses is as well scarce, even for Madagascar. In addition, as traditional knowledge is transmitted orally from generation to generation, its loss begins to be felt worldwide (Reyes-García et al. 2013). In the light of the prevalent loss and threatened future of this knowledge and cultures, it is currently a common practice for communities to document their knowledge (Maina 2012). This study is as such important because it reports and documents on the traditional knowledge of aquatic plant uses in the Alaotra communities, which largely contributes to prevent the loss of knowledge in this area due to ongoing anthropogenic pressures on the lake and the marshes.

While floristic studies were conducted at Lake Alaotra by Ranarijaona (1999) as part of her study to conceive a typology of Malagasy lentic waters, most of the biological research conducted in the area have been focused on population biology, distribution and behavior of vertebrate species, especially on Hapalemur alaotrensis (the Critically Endangered Alaotran gentle lemur), as well as on bird and fish species (Wilmé 1994, Waeber and Hemelrijk 2003, Ralainasolo 2004, Ralainasolo et al. 2006, René de Roland et al. 2009, Guillera-Arroita et al. 2010). Furthermore, almost nothing has been published on the use of marsh and lake plants by the Sihanaka ethnic group, the dominant ethnic group around the Lake, despite their continuing adherence to traditional practices. Past studies only contained sporadic reports of plant uses (Ranarijaona 2007, Lammers et al. 2015, Rakotoarisoa et al. 2015, Rendigs et al. 2015, Rakotoarisoa et al. 2016). While Pidgeon provided a plant inventory already in 1996, the present study is the first with a structured approach for an exhaustive assessment of local plants as well as their respective uses in the Lake Alaotra region.

In Madagascar, the Missouri Botanical Garden (MBG) is an organization working on research and conservation of the Malagasy flora, action that initially focused on terrestrial ecosystems. Since 2010, MBG has given a special interest to wetlands ecosystems and has started inventorying plant species of Malagasy wetland habitats including those from rivers, lakes and marshes. However, there are still many geographical gaps in this inventory. To address the issue, a collaboration with Madagascar Wildlife Conservation (MWC), under the Alaotra Resilience Landscape (AlaReLa) project, was then established to complete information on freshwater plant uses in Lake Alaotra area. This study undertaken following this collaboration has the objectives to (i) inventory plant species occurring in the lake and the marshes, especially in the Park Bandro and its surroundings, and (ii) record ethnobotanical information on the uses of these wetland plants.

\section{METHODS}

STUDY SITE. The Alaotra wetlands are located in the Alaotra-

Mangoro Region, within Ambatondrazaka and Amparafaravola districts, and about $250 \mathrm{~km}$ northeast of Antananarivo. It is a complex ecosystem with a variety of habitats that includes open water, marsh, reed beds (dominated by papyrus, cyperus papyrus subsp. madagascariensis, and common reed, Phragmites australis), and rice fields (Wallace 2012). The lake itself covers a surface area of some 20,000 ha and it is surrounded by 20,000 ha of marshland and 120,000 ha of rice fields (Mutschler 2003, Reibelt et al. 2017a).

Historically, the first observations on Lake Alaotra at the beginning of the 20th century showed that it had an area of 200,000 ha of which 25,000 ha was lake and the rest marshes (Moreau 1980). The first data on the hydrological regime of the lake and the first accurate bathymetric information were published by Longuefosse (1923). A recent study deduced that the lake once occupied more than 100,000 ha, thus with a present area of just 20,000 ha, the lake is now only $20-30 \%$ of its former size (Bakoariniaina et al. 2006). Different studies carried out after Madagascar's independence indicated that the marshes covered an area of 55,000 ha in 1961 (Thérézien 1963), 35,000 ha in 1974 (Moreau 1977), 30,000 ha in 1976 (Moreau 1987), and about 20,000 ha in 1994 (Mutschler and Feistner 1995, Mutschler et al. 1995, Mutschler 2003). Large areas of marshland have also disappeared and the remaining surface area is now considered less than $25 \%$ of the original area (Guillera-Arroita et al. 2010). Because of such observations, Moreau (1977) concluded that Lake Alaotra, in its present state, is a mere vestige of a much larger lake which, on the scale of geological time, is about to disappear. However, a more recent study by Mietton et al. (2018: 22) gives conflicting 
information: "Lake Alaotra has been in existence for at least 30,000 years, with evidence of climatically-driven fluctuations but no evidence of the lake ever being much larger or having occupied the entire floor of the topographic basin". Besides, "(...) the lake was not, unlike some claims to the contrary, threatened by imminent decline" (Ferry et al. 2013, Mietton et al. 2018: 37).

Located at the southeastern shore of the lake (Figure 1), in Ambatondrazaka district, the 85 ha Park Bandro was established as a special conservation zone in 2004 and is now nested within the newly-designated and much larger Lake Alaotra Protected Area (Reibelt et al. 2017a). Recently, the remaining area of marsh within this Park Bandro was estimated as 43 ha (Raveloarimalala and Reibelt 2017). The park was created by the local VOI (vondron' olona ifotony, a local community association for natural resource management) from the nearby village of Andreba with support from the conservation organizations Durrell Wildlife Conservation Trust and Madagascar Wildlife Conservation (Reibelt et al. 2017a). The park is of high conservation importance, as it hosts the biggest known subpopulation of Hapalemur alaotrensis or bandro (local name), a lemur species that is found only in the Alaotra marshes (IUCN 2014, Reibelt et al. 2017b). The population in Park Bandro was estimated as more than 170 individuals in 2013 but only 40-80 in 2017 (Ratsimbazafy et al. 2013, Raveloarimalala and Reibelt 2017). The park, with the marshes and the rice fields in its surroundings, was chosen to conduct the fieldwork. The study was focused on this small area as it is less affected by fire and human impact, thus a place where natural vegetation community likely continue to exist.

We decided to conduct ethnobotanical surveys on plant use by local people in Andreba (S17 38' 05.1", E048 30' 25.3", 765 m)

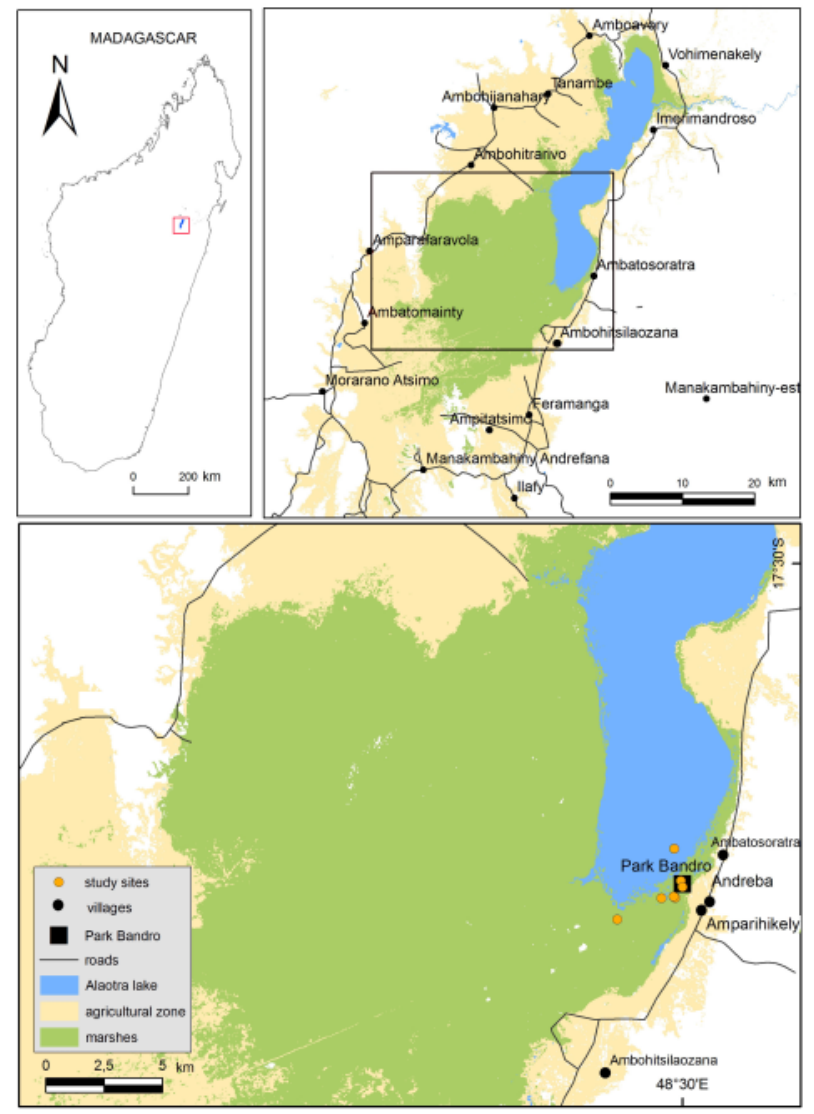

Figure 1. Location of the Park Bandro and the study sites. because this is the closest village to Park Bandro, and its population depends on the lake and its marshes for their livelihoods. Like all the villages surrounding Lake Alaotra, the ca. 5000 inhabitants of Andreba rely primarily on rice cultivation and fishing as a source of income (Rakotoarisoa et al. 2015). They also use plant species in the marsh and its surroundings to get raw materials, for example, for construction, handicrafts and even to treat diseases (Rendigs et al 2015).

ETHNOBOTANICAL SURVEYS. Fieldwork was conducted in December 2016 and January 2017, a period when most flowering plants are fertile. Surveys were conducted with 30 informants from Andreba village including key informants (someone who has a profound knowledge on plant uses) such as one tangalamena, the traditional chief of the village, and one traditional healer called reninjaza. Two members of the local Vol served us as guides during the surveys and helped us to identify the participants who were likely knowledgeable about plants and their uses.

Free listing and semi-structured interviews (Martin 1995, Alexiades 1996, Gerique 2006) were carried out with informants to record information on useful plants, such as vernacular names, plant uses and plant part used, and in-depth interviews were held with the two key informants for more information. The free listing method consists on asking informants to list useful plants they know with their uses. Semi-structured interviews consist of a series of general questions that are used as a guide for the interview topics; it is more flexible than structured interviews, as it allows other questions than the pre-defined ones to be raised and answered. Most important questions ask which plants the informant takes from Lake Alaotra and its surroundings and for what purpose, what plants are collected for cultural uses, and which ones are used for healing? As techniques of inquiry, individual and group interviews, artifact interview, plant interview and field interview were performed (Alexiades 1996, Gerique 2006). In addition to individual interviews, group interviews were conducted based on the assumption that some people will be more willing to share their knowledge in a group environment (Gerique 2006). Artifact interview consists on asking informants about the plants, which were employed in the manufacture or preparation of particular items like baskets or tools. Plant interview consists on collecting plants in the field, bringing them back to the village and present them to informants. Field interview consists on walking in the Park Bandro and its surroundings with the two local guides and asking them about plants and their uses while collecting them.

For ethical consideration, prior informed consent was asked for from all participants before each interview in the respect of the Nagoya Protocol on access to genetic resources and fair and equitable sharing of benefits arising from their use (Secretariat of the Convention on Biological Diversity 2011). The proposal for ethical research conduct in Madagascar was also followed during the study (Wilmé et al. 2016)

Types of plant use were categorized using the classification established by Cámara-Leret et al. (2012). It is a standard protocol used for gathering ethnobotanical data on palms, but was used in this study as it describes more details on different types of plant use within ten use-categories which are 'animal food', 'construction', 'cultural uses', 'environmental uses', 'fuel', 'human food', 'medicinal and veterinary', 'toxic', 'utensils and tools', and 
'other uses' not covered by the previous categories. Vouchers herbarium specimens of each of the plant species cited by informants were collected to enable scientific identification. Plant identification consists on using dichotomous keys for many diagnostic features and on comparing the voucher specimens with properly identified herbarium specimens. General botanical inventory was also conducted using this method. All vouchers were collected in replicate and specimens deposited at the national herbarium (known by the acronym TAN) and the two international herbaria with large botanical collections from Madagascar at Missouri Botanical Garden (MO) and the Muséum national d'Histoire naturelle (P). Digital images of plant species were also taken during the fieldwork. Those species for which voucher herbarium specimens could not be made during our fieldwork were identified using images provided by the staff of the Madagascar Wildlife Conservation. Coordinates of the collection locations were taken and are shown on the map in Figure 1.

Data analysis was performed by using Anthropac $® 1.0$ (Borgatti 1996), a qualitative data analysis software to evaluate the degree of knowledge of a domain by the informant. The results were expressed as frequency of citation (\%) and salience (a value that lies between 0 and 1) (Borgatti 1999, Quinlan 2005). Frequency is considered as the repetition of citations during the surveys, in which one specific use of one plant part of one species by one informant is counted as one citation. Salience is a statistic accounting for rank and frequency of species citation in which one species is considered more salient when it appears more often and earlier in freelists. In this study, the most frequent and most salient species were considered most important for the local population. Statistical analysis using Mann-Whitney $U$ test at alpha 0.05 was used to assess the difference of knowledge between men and women.

\section{RESULTS}

INFORMANTS' KNOWLEDGE. In total, 30 informants were interviewed. Of these, 15 were women and 15 were men, ageing from 22 to 84 years old. They are all farmers, especially rice cultivators, but some (7\%) also practice fisheries and weaving. In general, informants were assumed to get knowledge on plant uses because they were used to life in the lake and marshes, but they may also inherit it from their parents or relatives.

A total of 84 aquatic plant species were recorded during the study. They are grouped into 60 genera and 29 plant families. Sixtyeight of them, belonging to 47 genera and 23 families, were collected in the field with vouchers. For the remaining, 14 were identified using images except for two species of Ipomoea L. that we did not find during the floristic inventory of Park Bandro and its surroundings.
A total of 55 species, belonging to 23 families and 41 genera, were cited as useful by the local population. Most of them (87\%) are herbs, with the remaining species including five liana species, one shrub and one tree. Two species (Emilia citrina DC. and Zehneria rutenbergiana (Cogn.) Keraudren) were endemics, 36 native and 17 naturalized. The most represented plant families were Poaceae with 11 useful species, Cyperaceae (7), and Asteraceae and Fabaceae (five species each). The most representative genus was Cyperus $\mathrm{L}$. with five species. The men knew $91 \%$ of the 55 useful plants recorded while the women knew $58 \%$ (Table 1). On average, men cited 9 species ( \pm 1.4 standard error SE) and 13 types of uses $( \pm 2.6 \mathrm{SE}$ ) per informant while women cited respectively 7 ( $\pm 1.2 \mathrm{SE}$ ) and 10 ( $\pm 1.8 \mathrm{SE}$ ). There was no significant difference of knowledge between the two genders for both the number of plant species cited as being useful and the plant uses recorded with $p>0.05$ each.

Within the age categories, informants in the age class 51 to 60 years cited on average 12 species ( $\pm 2.9 \mathrm{SE}$ ) and 19 types of uses ( \pm $4.2 \mathrm{SE}$ ) per informant more than the others.

PLANT USES. For the 55 useful plant species, about 115 types

of uses were recorded within eight major use-categories as defined by Cámara-Leret et al. (2012). Most species were recorded in the category 'medicinal and veterinary' (32 species), followed by 'animal food' (17), 'utensils and tools' (16), 'cultural uses' (10), 'human food' (9), 'construction' (6), 'fuel' (4) and 'environmental uses' (3) (Supplementary Material). An analysis of the data obtained from free listing highlighted 13 species of greatest importance for the local population with a frequency of citation (FC) higher than $25 \%$, with number of uses varying from 5 to 26 (Table 2). The most important were Nymphaea nouchali Burm. f., Cyperus papyrus subsp. madagascariensis (Willd.) Kük., Phragmites australis (Cav.) Trin. ex Steud. and Ethulia conyzoides L. f. with FC > 50\%. Nymphaea nouchali was the most frequent as well as the most salient species cited because it is mostly used by the local population. Leaves (76\%) were the most important plant part used.

Regarding the types of use, the most frequently cited were joro or ancestors' invocation ( $\mathrm{FC}=63 \%$ ), food ( $\mathrm{FC}=57 \%$ ), house walls, herbal teas and fences or demarcation of land boundaries ( $F C=50 \%$ each). The use of aquatic plants to produce mats had an $\mathrm{FC}$ of $40 \%$. Six species were used as part of various ceremonies to invoke ancestors (e.g., circumcision, house building, marriage), of which Cyperus papyrus subsp. madagascariensis ( $F C=90 \%$ ) and Nymphaea nouchali $(F C=84 \%)$ were the most important.

Among the six species having at least 10 different uses (Table 2), Cyperus papyrus subsp. madagascariensis and Phragmites australis (the most used species) were among those used in the top ten uses (Table 3). They were both mainly cited for construction

Table 1. Informants' knowledge in Andreba village according to gender and age categories.

\begin{tabular}{ccccccc} 
& & $\begin{array}{c}\text { Total number } \\
\text { of people } \\
\text { interviewed }\end{array}$ & $\begin{array}{c}\text { Total of } \\
\text { species } \\
\text { recorded }\end{array}$ & $\begin{array}{c}\text { Average number of } \\
\text { species cited per } \\
\text { informant (min-max) }\end{array}$ & $\begin{array}{c}\text { Total of } \\
\text { plant uses } \\
\text { recorded }\end{array}$ & $\begin{array}{c}\text { Average number of } \\
\text { plant uses cited per } \\
\text { informant (min-max) }\end{array}$ \\
\hline Gender & Men & 15 & 50 & $9(3-19)$ & 90 & $13(2-37)$ \\
& Women & 15 & 32 & $7(1-19)$ & 69 & $10(1-24)$ \\
\hline \multirow{6}{*}{ Age } & {$[20-30]$} & 4 & 14 & $4(2-8)$ & 11 & $4(2-8)$ \\
& {$[31-40]$} & 4 & 29 & $9(1-19)$ & 36 & $10(1-20)$ \\
categories & {$[41-50]$} & 7 & 15 & $6(2-8)$ & 38 & $9(6-13)$ \\
& {$[51-60]$} & 5 & 31 & $12(6-19)$ & 55 & $19(8-31)$ \\
& {$[61-70]$} & 5 & 26 & $9(3-14)$ & 44 & $13(5-23)$ \\
& {$[71+]$} & 5 & 20 & $8(5-16)$ & 49 & $14(2-37)$ \\
\hline
\end{tabular}


Table 2. Species mostly used by the local population of Andreba.

\section{Family Scientific name}

Nymphaeaceae Nymphaea nouchali Burm. f.

Cyperaceae Cyperus papyrus subsp. madagascariensis (Willd.) Kük.

Poaceae

Asteraceae Phragmites australis (Cav.) Trin. ex Steud.

Convolvulaceae cuscuta campestris Yunck.

Lamiaceae

Onagraceae

Cyperaceae

Molluginaceae

Fabaceae

Pontederiaceae

Onagraceae

Araceae
Pycnostachys coerulea Hook.

Ludwigia adscendens subsp. diffusa (Forssk.) P.H. Raven

Cyperus latifolius Poir.

Glinus oppositifolius (L.) Aug. DC.

Aeschynomene elaphroxylon (Guill. \& Perr.) Taub.

Eichhornia crassipes (Mart.) Solms

Ludwigia octovalvis (Jacq.) P.H. Raven

Typhonodorum lindleyanum Schott
Vernacular names

Betsimihilana, tatamo, voahirana

Zozoro

Bararata

Revaka, Revaka mena

Tsihitafototra

Mihorondoa, Revaka fotsy

Bonaka

Vendrana

Anamafaitra

Dofonga

Tsikafona

Felangoaka, hazomena

Viha

\begin{tabular}{ccc} 
Frequency (\%) & Salience & Number of uses \\
\hline 70 & 0.33 & 6 \\
67 & 0.22 & 26 \\
60 & 0.32 & 19 \\
57 & 0.31 & 8 \\
47 & 0.19 & 10 \\
40 & 0.27 & 5 \\
33 & 0.17 & 8 \\
33 & 0.13 & 10 \\
30 & 0.12 & 6 \\
30 & 0.10 & 12 \\
30 & 0.10 & 12 \\
30 & 0.09 & 9 \\
27 & 0.08 & 6
\end{tabular}

( $F C=75 \%$ each). A comparison of the uses of the two species showed that both species were used to invoke ancestors, for fence construction and for house walls whereas Cyperus papyrus subsp. madagascariensis alone was used for food and mat and basket weaving, and Phragmites australis alone was used for roof supports. Cyperus papyrus subsp. madagascariensis was one of the three most cited species (with Cyperus latifolius Poir. and Eichhornia crassipes (Mart.) Solms) used in basketry. For the other species, Cyperus latifolius is used to make roofs. Aeschynomene elaphroxylon (Guill. \& Perr.) Taub. was not used for any of the top 10 uses as it was mainly used to make artisanal chairs and some toys for children.

In terms of medicinal plants, 32 species recorded were used for human medicine providing 44 different treatments. Only one species, Gomphocarpus fruticosus (L.) W.T. Aiton, was used both for human and animal medicine. Frequently cited medicinal plants included Ethulia conyzoides ( $F C=61 \%)$, Cuscuta campestris Yunck. $(F C=46 \%)$ and Pycnostachys coerulea Hook. ( $F C=43 \%)$. They were mainly administered as herbal teas, and used to treat colic and stomach ache.

For the other uses, Eichhornia crassipes ( $F C=42 \%$ ) was mostly cited being useful as fodder, especially for pigs. Nymphaea nouchali $(F C=63 \%)$, Glinus oppositifolius (L.) Aug. DC. ( $F C=47 \%)$ and Typhonodorum lindleyanum Schott ( $F C=42 \%$ ) were mainly

cited as human food, of which tubers, leaves and seeds respectively were the part consumed. Aeschynomene elaphroxylon, cyperus papyrus subsp. madagascariensis and Phragmites australis can serve as fuel, and Eichhornia crassipes was sometimes used to make charcoal. The three species known to be invasive in wetland ecosystems, Azolla pinnata R. Br., Eichhornia crassipes, Salvinia molesta D.S. Mitch., were all used to make compost.

\section{DISCUSSION}

In terms of plant inventory, the number of plant species recorded for Lake Alaotra varies from 22 to 84 depending on the type of study and methods applied. Pidgeon (1996) first recorded 23 species. Three years later, Ranarijaona (1999) inventoried 42 species, and about eight years later, recorded only 35 out of the 42 that the author assumed to be present in the area (Ranarijaona 2007). Recently, only 22 species were recorded by Lammers et al. in 2015 and 33 two years later (Lammers et al. 2017). But no plant lists were provided by Pidgeon (1996), Ranarijaona (2007) and Lammers et al. (2015).

In comparison to Ranarijaona's (1999) and Lammers et al.'s (2017) plant lists, our results presented a high number of plant species recorded (84) for the lake and the wetlands in its surroundings (marshes and rice fields). The comparison of the

Table 3. Species recorded for the top ten uses cited by the informants.

\begin{tabular}{|c|c|c|c|}
\hline Plant uses & Frequency (\%) & Salience & Species used \\
\hline $\begin{array}{l}\text { Joro or } \\
\text { ancestors' } \\
\text { invocation }\end{array}$ & 63 & 0.30 & $\begin{array}{l}\text { Azolla pinnata R. Br., Commelina madagascarica C.B. Clarke, Cyperus papyrus subsp. madagascariensis (Willd.) } \\
\text { Kük., Hydrocotyle bonariensis Lam., Nymphaea nouchali Burm. f., Phragmites australis (Cav.) Trin. ex Steud. } \\
\text { Alternanthera sessilis (L.) R. Br. ex DC., Cyperus latifolius Poir., Cyperus papyrus subsp. madagascariensis (Willd.) }\end{array}$ \\
\hline Food & 57 & 0.20 & $\begin{array}{l}\text { Kük., Glinus oppositifolius (L.) Aug. DC., Grangea lyrata (DC.) Fayed, Ipomoea aquatica Forssk., Ipomoea sp.1 L., } \\
\text { Nymphaea nouchali Burm. f., Typhonodorum lindleyanum Schott } \\
\text { Cyperus papyrus subsp. madagascariensis (Willd.) Kük., Phragmites australis (Cav.) Trin. ex Steud. }\end{array}$ \\
\hline House walls & 50 & 0.38 & Cuscuta campestris Yunck., Ethulia conyzoides L. f., Glinus oppositifolius (L.) Aug. DC., Pycnostachys coerulea \\
\hline Herbal teas & 50 & 0.34 & $\begin{array}{l}\text { Hook. } \\
\text { Cyperus papyrus subsp. madagascariensis (Willd.) Kük., Phragmites australis (Cav.) Trin. ex Steud. }\end{array}$ \\
\hline $\begin{array}{l}\text { Fences or land } \\
\text { boundaries }\end{array}$ & 50 & 0.32 & Cyperus latifolius Poir., Cyperus papyrus subsp. madagascariensis (Willd.) Kük., Eichhornia crassipes (Mart.) \\
\hline Mats & 40 & 0.29 & $\begin{array}{l}\text { Solms } \\
\text { Ethulia conyzoides L. f., Ludwigia octovalvis (Jacq.) P.H. Raven, Parthenium hysterophorus L., Pycnostachys }\end{array}$ \\
\hline Colic & 37 & 0.16 & $\begin{array}{l}\text { Coerulea Hook. } \\
\text { Eichhornia crassipes (Mart.) Solms, Ludwigia adscendens subsp. diffusa (Forssk.) P.H. Raven, Nymphaea }\end{array}$ \\
\hline Fodder for pigs & 33 & 0.09 & $\begin{array}{l}\text { nouchali Burm. f., Typhonodorum lindleyanum Schott } \\
\text { Phragmites australis (Cav.) Trin. ex Steud. }\end{array}$ \\
\hline Roof supports & 30 & 0.23 & Cyperus latifolius Poir., Cyperus papyrus subsp. madagascariensis (Willd.) Kük., Eichhornia crassipes (Mart.) \\
\hline Baskets & 27 & 0.13 & Solms \\
\hline
\end{tabular}


three lists showed that 22 species (about half of that of Ranarijaona (1999)) were shared with Ranarijaona's (1999) list and 20 with Lammers et al.'s (2015). This means that in comparison to the two studies we recorded 53 species from this site for the first time. This difference may be due to the methods used by each author. For example, transects were used by Ranarijaona (1999) for vegetation typology and plant inventories while Lammers et al. (2015) employed plots of $100 \mathrm{~m} 2$ to evaluate the habitat quality inside and outside of the Park Bandro. For our study, we aimed to inventory all useful plants in the lake and its wetlands, but in addition we endeavored to identify all flowering and/or fruiting plants encountered at the study site, whether or not they were cited as useful by the informants. Local guides helped us to conduct the inventory allowing us to maximize the number of plants encountered. However, we did not find some of the species that Ranarijaona (1999) and Lammers et al. (2017) had recorded during their inventories, which totals 31 species. Some of those species might not have been fertile during our field period, but others could only be missed in the collection locations where we did the inventories. The combination of our plant list with Ranarijaona's (1999) and Lammers et al.'s (2017) lists would give a total number of 115 plant species for Lake Alaotra and its wetlands, i.e., near $34 \%$ of the 338 aquatic and semi-aquatic plant species known for Madagascar based on the bibliographical study made by Ranarijaona (1999) and 24\% of the 489 species recently assessed by the Missouri Botanical Garden. Thus, Lake Alaotra retains a diverse flora that deserves conservation not only because of its importance to local people but also as a resource for scientific research, for example, for ethnobotanical studies. Compared with other wetlands in Madagascar, Lake Alaotra always has the highest plant biodiversity richness with 42 plant species recorded in 1999 (Ranarijaona 1999: 110) and 115 species estimated in this study. The loss of such diversity may lead to the loss of traditional knowledge on plant uses, a phenomenon that has already been observed worldwide (Reyes-García et al. 2013). Furthermore, the loss of Lake Alaotra plant diversity could indeed lead to the loss of its unique lemur's habitats and thus the loss of Madagascar's biodiversity patrimony, which makes it one of the most important Ramsar sites.

Several other authors have commented on the use of Lake Alaotra's plants by the local community. According to this study, Cyperus papyrus subsp. madagascariensis and Phragmites australis were the most used plants because in addition to being dominant species in the marshland, they were used for constructing houses, fences, animal shelters, handicrafts, fish traps as well as during traditional ceremonies. Ranarijaona (2007) noted the importance of Cyperus papyrus subsp. madagascariensis and cyperus latifolius as raw materials for mat and basket weaving, while Rendigs et al. (2015) reported their uses for construction purposes and handicrafts. However, it has been recently observed that the current exploitation of Cyperus papyrus subsp. madagascariensis in the region contributes to pressures causing a reduction in Lake Alaotra's wetlands and notably decreases habitat and food resources for the Alaotran gentle lemur. Rakotoarisoa et al. (2016) evaluated the use of Eichhornia crassipes, one of the "100 worst invasive alien species" (Lowe et al. 2000) and among the 10 most troublesome floating weeds of the world (Lancar and Krake 2002), as an alternative source of raw materials for handicrafts. Rendigs et al. (2015) also reported the use of Nymphaea nouchali in traditional ceremonies and Ethulia conyzoides and Cuscuta campestris as medicine. Ranarijaona (2007) reported the importance of aquatic plants for medicine.

Apart from the utility of the plants growing in Alaotra's wetlands, Rendigs et al. (2015) and Waeber et al. (2017) noted the importance of Alaotra marshland in providing a range of important ecosystem services to the communities of adjacent villages. Unfortunately, continuous anthropogenic pressures on Alaotra wetlands are altering both the water body and the associated vegetation, leading to the formation of new plant communities in the fringe area of the marsh belt characterized by fast growing species like Ludwigia adscendens subsp. diffusa (Forssk.) P.H. Raven and Echinochloa pyramidalis (Lam.) Hitchc. \& Chase (Lammers et al. 2015). Such changes will lead for some plant species, including some useful plants becoming increasingly rare or maybe even locally extinct. For example, Cyperus latifolius was not found during our exploration in the marsh, and now occurs only rarely outside the study site. Furthermore, the spread of invasive and disturbance-tolerant alien species (e.g., Azolla pinnata, Eichhornia crassipes, Salvinia molesta) represents a major threat to native freshwater plants, ecosystems and local livelihoods (Rakotoarisoa et al. 2015, Rendigs et al. 2015). In addition, relationship between biodiversity, traditional practices and traditional knowledge is also evident, which should be considered in any future management plans in order to preserve its biodiversity and cultural values.

\section{CONCLUSION}

Alaotra marshlands are important for supporting local livelihoods and providing crucial ecosystem services for the local population, thus also contributing to the area's cultural heritage. Our study emphasizes the important relationship between Alaotra's plants and local people. Plant species used by the riparian population are mainly collected in the lake and its surroundings, and are used in a variety of ways including traditional ceremonies, medicine, construction, weaving, and even for livestock. Fifty-five plant species out of the 84 recorded during the study were revealed to be useful. Unfortunately, continuous human pressures are impacting the area's flora and are leading to the increasing rarity of some important useful species. While the current benefits of aquatic plants are significant and far-reaching, new uses may be discovered in the future. As some species become rare, it is likely that traditional knowledge of their plant use will also be eroded and perhaps lost. Such loss of traditional knowledge on plant uses has been observed in many regions in the world. Accordingly, strategies for long term sustainable management of freshwater wetlands are required taking into account to their ecological functions and the goods and services they provide, and further documentation of traditional knowledge concerning aquatic plant uses is necessary to ensure that it is captured before it is lost.

\section{ACKNOWLEDGMENTS}

The authors would like to thank Madagascar Wildlife Conservation (MWC) and its staff for their technical support during the study, particularly Patrick O. Waeber, Lucienne Wilmé and Lucile Raveloarimalala for their assistance and coordination; Ihoby Henintsoa Randriamalala for providing the map shown in Figure 1; Randrianilaina Manamiranto, Nomenjanahary Lala and Rakotoarivony Katuiscia for their assistance in the field. We are especially grateful to the local population of Andreba Gara for 
generously sharing ethnobotanical knowledge on useful aquatic plants without which this study would not have been possible. We would like also to thank Chris Birkinshaw for comments on an earlier draft of this manuscript. This research was funded by the Swiss Program for Research on Global Issues for Development under research grant IZ01Z0_146852 as part of the AlaReLa Alaotra Resilience Landscape project.

\section{REFERENCES}

Alexiades, M. N. 1996. Collecting ethnobotanical data: An introduction to basic concepts and techniques. In: Selected Guidelines for Ethnobotanical Research: A Field Manual. Alexiades, M. N. (ed.), pp 53-94. The New York Botanical Garden, Bronx, New York.

Andrianandrasana, H. T., Randriamahefasoa, J., Durbin, J., Lewis, R. E. and Ratsimbazafy, J. H. 2005. Participatory ecological monitoring of the Alaotra wetlands in Madagascar. Biodiversity and Conservation 14, 11: 2757-2774. $<$ https://doi.org/10.1007/s10531-005-8413-y>

Bakoariniaina, L. N., Kusky, T. and Raharimahefa, T. 2006. Disappearing Lake Alaotra: Monitoring catastrophic erosion, waterway silting, and land degradation hazards in Madagascar using Landsat imagery. Journal of African Earth Science 44: 241-252. <https://doi.org/10.1016/j.jafrearsci.2005.10.013>

Borgatti, S. P. 1996. AnthroPac 4 Methods Guide. Analytic Technologies, Natick.

Borgatti, S. P. 1999. Elicitation methods for cultural domain analysis. In: The Ethnographer's Toolkit, Volume 3. J. Schensul and M. LeCompte (eds.) pp 115151. Altamira Press, Walnut Creek, USA.

Cámara-Leret, R., Paniagua-Zambrana, N. and Macía, M. J. 2012. A standard protocol for gathering palm ethnobotanical data and socioeconomic variables across the tropics. In: Medicinal plants and the legacy of Richard E. Schultes. B. Ponman and R. W. Bussmann (eds.), pp 41-71. Proceedings of the Botany 2011, Richard E. Schultes Symposium, Graficart, Trujillo.

Chaperon, P., Danloux, J. and Ferry, L. 1993. Fleuves et Rivières de Madagascar. Collection Monographie Hydrologique n¹0. Éditions de I'ORSTOM, Paris, France. Available <https://goo.gl/yYp8sY>

Copsey, J. A., Rajaonarison, L. H., Randriamihamina, R. and Rakotoniaina, L. J. 2009. Voices from the marsh: Livelihood concerns of fishers and rice cultivators in the Alaotra wetland. Madagascar Conservation \& Development 4, 1:24-30. $<$ https://doi.org/10.4314/mcd.v4i1.44008>

Darwall, W. R. T., Smith, K. G., Allen, D. J., Holland, R. A, Harrison, I. J. and Brooks, E. G. E. (eds.). 2011. The Diversity of Life in African Freshwaters: Under Water, Under Threat. An analysis of the status and distribution of freshwater species throughout mainland Africa. IUCN, Cambridge, United Kingdom and Gland, Switzerland.

Ferry, L., Mietton, M., Touchart, L. and Hamerlynck, O. 2013. Lake Alaotra (Madagascar) is not about to disappear. Hydrological and sediment dynamics of an environmentally and socio-economically vital wetland. Dynamiques Environnementales 32: 105-122. Available <https://hal.archives-ouvertes.fr/ hal-01122412>

Gerique, A. 2006. An introduction to ethnoecology and ethnobotany, theory and methods. In: Integrative assessment and planning methods for sustainable agroforestry in humid and semiarid regions. Advanced Scientific Training (ed.), 20p. Loja, Ecuador.

Guillera-Arroita, G., Lahoz-Monfort, J. J., Milner-Gulland, E. J. and Young, R. P. 2010 Monitoring and conservation of the critically endangered Alaotran gentle lemur Hapalemur alaotrensis. Madagascar Conservation \& Development 5, 2 : 103-109. <http://doi.org/10.4314/mcd.v5i2.63140>

IUCN (International Union for Conservation of Nature). 2014. Hapalemur alaotrensis. The IUCN Red List of Threatened Species 2014: e.T9676A16119362. Accessed 20 July $2018<$ http://dx.doi.org/10.2305/IUCN.UK.20141.RLTS.T9676A16119362.en>

Lammers, P. L., Richter, T., Waeber, P. O. and Mantilla-Contreras, J. 2015. Lake Alaotra wetlands: how long can Madagascar's most important rice and fish production region withstand the anthropogenic pressure? Madagascar Conservation \& Development 10, S3: 116-127. <https:// doi.org/10.4314/ mcd.v10i3.4>
Lammers, P. L., Richter, T., Lux, M., Ratsimbazafy, J and Mantilla-Contreras, J. 2017. The challenges of community-based conservation in developing countries A case study from Lake Alaotra, Madagascar. Journal for Nature Conservation 40: 100-112. <https://doi.org/10.1016/j.jnc.2017.08.003>

Lancar, L. and Krake, K. 2002. Aquatic weeds and their management. International Commission on Irrigation and Drainage (ICID). Available <http://www.icid.org/ weed_report.pdf>

Longuefosse, J. 1923. L'Antsihanaka - Région du lac Alaotra à Madagascar. Bulletin Economique 20, 1:111-134.

Lowe, S., Browne, M., Boudjelas, S. and De Poorter, M. 2000. 100 of the world's worst invasive alien species - A selection from the global invasive species database. The Invasive Species Specialist Group (ISSG). Available <https:// portals.iucn.org/library/sites/library/files/documents/2000-126.pdf>

Maina, C. K. 2012. Traditional knowledge management and preservation: Intersections with Library and Information Science. International Information \& Library Review 44, 1: 13-27. <https://doi.org/ 10.1080/10572317.2012.10762911>

Martin, G. J. 1995. Ethnobotany. A "People and Plants" Conservation Manual. World Wide Fund for Nature, Chapman \& Hall, London.

McCartney, M., Rebelo, L-M., Senaratna Sellamuttu, S. and de Silva, S. 2010. Wetlands, agriculture and poverty reduction. International Water Management Institute (IWMI), Research Report 137, Colombo, Sri Lanka. $<$ https://doi.org/10.5337/2010.230>

Mietton, M., Gunnell, Y., Nicoud, G., Ferry, L., Razafimahefa, R. and Grandjean, P. 2018. 'Lake' Alaotra, Madagascar: A late Quaternary wetland regulated by the tectonic regime. Catena 165: 22-41. <https://doi.org/10.1016/ j.catena.2018.01.021>

Moreau, J. 1977. Le lac Alaotra à Madagascar, évolution géographique passée et actuelle. Annales de Limnologie 13, 3: 261-274. <https://doi.org/10.1051/limn/ $1977016>$

Moreau, J. 1980. Le lac Alaotra à Madagascar : cinquante ans d'aménagement des pêches. Cahiers O.R.S.T.O.M., série Hydrobiologie 13, 3-4: 171-179. Available $<$ http://www.documentation.ird.fr/hor/fdi:00205>

Moreau, J. 1987. Madagascar. In: African Wetlands and Shallow Water Bodies. M. J. Burgis and J. J. Symoens (eds.), pp 595-650. ORSTOM, Collection Travaux et Documents n²11, Paris

Mutschler, T. 2003. Lac Alaotra. In: The Natural History of Madagascar. S. M. Goodman and J. P. Benstead (eds.), pp 1530-1534. The University of Chicago Press, Chicago and London.

Mutschler, T. and Feistner, A. T. C. 1995. Conservation status and distribution of the Alaotran gentle lemur Hapalemur griseus alaotrensis. Oryx 29, 4: 267-274. <https://doi.org/10.1017/S0030605300021268>

Mutschler, T., Nievergelt, C. and Feistner, A. T. C. 1995. Human induced loss of habitat at Lac Alaotra and its effect on the Alaotran gentle lemur. In: Environmental Change in Madagascar. B. D. Patterson, S. M. Goodman and J. L. Sedlock (eds.), pp 35-36. The Field Museum of Natural History, Chicago.

Pidgeon, M. 1996. An Ecological Survey of Lake Alaotra and Selected Wetlands of Central and Eastern Madagascar in Analyzing the Demise of Madagascar Pochard Aythya innotata. Lucienne Wilmé (ed.), WWF, Antananarivo.

Quinlan, M. 2005. Considerations for collecting freelists in the field: examples from ethnobotany. Field Methods 17, 3: 1-16. <https://doi.org/ $10.1177 / 1525822 \times 05277460>$

Rakotoarisoa, T. F., Waeber, P. O., Richter, T. and Mantilla-Contreras, J. 2015. Water hyacinth (Eichhornia crassipes), any opportunities for the Alaotra wetlands and livelihoods? Madagascar Conservation \& Development 10, S3: 128-136. $<$ https://doi.org/10.4314/mcd.v10i3.5>

Rakotoarisoa, T. F., Richter, T., Rakotondramanana, H. and Mantilla-contreras, J. 2016 Turning a problem into profit: Using Water Hyacinth (Eichhornia crassipes) for making handicrafts at Lake Alaotra, Madagascar. Economic Botany 70, 4: 365379. <https://doi.org/10.1007/s12231-016-9362-y>

Ralainasolo, F. B. 2004. Action des effets anthropiques sur la dynamique de la population de Hapalemur griseus alaotrensis ou Bandro dans son habitat naturel. Lemur News 9: 32-35. 
Ralainasolo, F. B., Waeber, P. O., Ratsimbazafy, J., Durbin, J. and Lewis, R. 2006. The Alaotra gentle lemur. Population estimation and subsequent implications. Madagascar Conservation \& Development 1, 1: 9-10. <http://dx.doi.org/ 10.4314/mcd.v111.44044>

Ramsar. 2003. Convention sur les Zones Humides - Fiche descriptive sur les zones humides Ramsar. Accessed 20 July 2018 <https://goo.gl/A8n6kZ>

Ramsar. 2018. The List of Wetlands of International Importance. Ramsar Sites Information Service. Available <https://goo.gl/uzTVQZ>

Ranarijaona, H. L. T. 1999. La Flore des Milieux Lentiques Malgaches (Lacs, Marais, Étangs) : Essai de Typologie. Unpubl. Thèse de Doctorat du 3e cycle, Université d'Antananarivo, Madagascar.

Ranarijaona, H. L. T. 2007. Concept de modèle écologique pour la zone humide Alaotra. Madagascar Conservation \& Development 2, 1: 35-42. <https:// doi.org/10.4314/mcd.v2i1.44128>

Ratsimbazafy, J. H., Ralainasolo, F. B., Rendigs, A., Contreras, J. M., Andrianandrasana, H., et al. 2013. Gone in a puff of smoke? Hapalemur alaotrensis at great risk of extinction. Lemur News 17: 14-18.

Raveloarimalala, L. M. and Reibelt, L. M. 2017. Update on the management of Park Bandro and population numbers of Hapalemur alaotrensis. Lemur News 20: 2.

Reibelt, L. M., Woolaver, L., Moser, G., Randriamalala, I. H., Raveloarimalala, L. M., et al. 2017a. Contact matters: local people's perceptions of Hapalemur alaotrensis and implications for conservation. International Journal of Primatology 38, 3: 588-608. <https://doi.org/10.1007/s10764-017-9969-6>

Reibelt, L. M, Ratsimbazafy, J. and Waeber, P. O. 2017b. Lac Alaotra gentle lemur Hapalemur alaotrensis Rumpler, 1975, Madagascar. In: Primates in peril: The World's 25 most endangered primates 2016-2018. Schwitzer, C., Mittermeier, R. A. and Rylands, A. B. et al. (eds.), pp 32-34. IUCN SSC Primate Specialist Group (PSG), International Primatological Society (IPS), Conservation International (Cl), and Bristol Zoological Society, Arlington, VA.

Rendigs, A., Reibelt, L. M., Ralainasolo, F. B., Ratsimbazafy, J. H. and Waeber, P. O. 2015. Ten years into the marshes marshes-Hapalemur alaotrensis conservation, one step forward and two steps back? Madagascar Conservation \& Development 10, 1S: 13-20. <https://doi.org/10.4314/ mcd.v10i1.s3>

René de Roland, L. A., Thorstrom, R., Razafimanjato, G., Rakotondratsima, M. P. H. and Sam, T. S. 2009. Surveys, distribution and current status of the Madagascar Harrier Circus macrosceles in Madagascar. Bird Conservation International 19, 4: 309-322. < https://doi.org/10.1017/S095927090900817X>

Reyes-García, V., Guèze, M., Luz, A. C., Paneque-Gálvez, J., Macía, M. J., et al. 2013. Evidence of traditional knowledge loss among a contemporary indigenous society. Evolution and Human Behavior 34, 4: 249-257. <https://doi.org/ 10.1016/j.evolhumbehav.2013.03.002>

Secretariat of the Convention on Biological Diversity. 2011. Nagoya Protocol on Access to Genetic Resources and the Fair and Equitable Sharing of Benefits Arising from their Utilization to the Convention on Biological Diversity. Secretariat of the Convention on Biological Diversity, United Nations, Montréal. Available <https://www.cbd.int/abs/>

Schuyt, K. and Brander, L. 2004. Living Waters: The Economic Values of the World's Wetlands. World Wide Fund (WWF), Gland/Amsterdam.

Thérézien, Y. 1963. Étude en Vue du Développement de la Pêche au Lac Alaotra. Doc. multigr. Centre Technique Forestier Tropical, Tananarive.

Waeber, P. O. and Hemelrijk, C. K. 2003. Female dominance and social structure in Alaotran gentle lemurs. Behaviour 140, 10: 1235-1246. <https://doi.org/ $10.1163 / 156853903771980576>$

Waeber, P. O., Reibelt, L. M., Randriamalala, I. H., Moser, G., Raveloarimalala, L. M., et al. 2017. Local awareness and perceptions: consequences for conservation of marsh habitat at Lake Alaotra for one of the world's rarest lemurs. Oryx 52, 4: 677-686. <https://doi.org/10.1017/S0030605316001198>

Wallace, A. P. C. 2012. Understanding fishers' spatial behavior to estimate social costs in local conservation planning. Unpubl. Ph.D. thesis, Imperial College, London. Available <http://hdl.handle.net/10044/1/10973>

Wilmé, L. 1994. Status, distribution and conservation of two Madagascar bird species endemic to Lake Alaotra: Delacour's grebe Tachybaptus rufolavatus and Madagascar pochard Aythya innotata. Biological Conservation 69, 1: 1521. <https://doi.org/10.1016/0006-3207(94)90324-7>
Wilmé, L., Waeber, P. O., Moutou, F., Gardner, C. J., Razafindratsima, O. et al. 2016. A proposal for ethical research conduct in Madagascar. Madagascar Conservation \& Development 11, 1: 36-39. <https://doi.org/10.4314/ mcd.v11i1.8>

\section{SUPPLEMENTARY MATERIAL}

Available online only

Useful plant species recorded in the Park Bandro and its surroundings, Lake Alaotra, Madagascar. 